\title{
The Effects of a Forest Therapy Program on the Self-Esteem and Resilience of Juveniles Under Protective Detention
}

\author{
In-Ok Kim ${ }^{1}$, Won-Sop Shin ${ }^{2 *}$, and Jin Young Jeon ${ }^{1}$ \\ ${ }^{1}$ Doctoral student, Graduate Department of Forest Therapy, Chungbuk National University, Cheongju 28864, Korea \\ ${ }^{2}$ Professor, Department of Forestry, Chungbuk National University, Cheongju 28864, Korea
}

\section{ABSTRACT}

Background and objective: Juvenile crimes tend to intensify and become habitual in South Korea and juvenile delinquencies must be corrected during adolescence. This study aimed to investigate the effects of a forest therapy program on the self-esteem and resilience of juveniles under protective detention.

Methods: We designed the forest therapy program titled “A Dreamy Child, One More Forest!" for one night and two days and a total of 122 juveniles under protective detention participated in the program. Self-esteem scale (SES) and resilience scale for adolescents (RSA) were used and the collected data were analyzed using frequency analysis and T-test.

Results: Most of the participants were male (96.7\%), and the number of those aged 17 years was highest (35, 28.7\%). The number of those enrolled in middle and high school was 69 (56.0\%) and that of those who dropped out was 39 (31.9\%). Their self-esteem significantly increased from 3.102 before participation to $3.636(p<.001)$ after participation in the forest therapy program. Resilience also increased remarkably from 2.950 before participation to $3.829(p<.001)$ after participation, showing positive changes after participation in both cases.

Conclusion: The results indicated the forest therapy program could enhance the self-esteem of juveniles under protective detention, provide them with an opportunity for developing their inner positive power and reinforcomg resilience, helping them return to society in a healthy state. Further research needs to be conducted on how the effects over the program period will differ from one another and how long the positive effects will last.

Keywords: forest, probation, walking, wellness

\section{Introduction}

Adolescent, so-called an age of storm and stress, is a transitional period from childhood to adulthood, and those in this period experience rapid physical development and build a new ego-identify based on consequent emotional and social development. Ego-identity must be built in the adolescent period, and those who are unable to build it properly face an identity crisis and an emotional turmoil (E.Y. Kim, 2014). As a way to avoid and escape from psychological depression caused by such emotional problems, some adolescents misbehave and such delinquent be- haviors are reported as a crime and are sentenced to protective detention by the court (the Juvenile Department) according to Subparagraphs 1-10, Article 32 (1) of the Juvenile Act. Those who are subject to Subparagraphs 4 and 5 are mostly classified as a 'juvenile under protective detention.' Their family background ranges from lack of affection, protection and support due to their parents' bereavement and divorce to wrong parenting styles or family discord, and their academic background shows maladjustment to school, the absence of positive relationships with teachers and problems in relationships with peers in school (bullying). In addition, their psychological and social state

Received: February 8, 2020, Revised: February 19, 2020, Accepted: July 8, 2020

First author: In-Ok Kim, inoya88@hanmail.net, (D) https://orcid.org/0000-0002-9926-9979

*Corresponding author: Won-Sop Shin, shinwon@chungbuk.ac.kr, (D) https://orcid.org/0000-0002-5665-1502 
can be characterized as low self-esteem, lack of control, high aggression, low expectation of the future and inappropriate relationships with peers, and their crimes are mostly opportunist crimes, which indicates the dangerousness of spontaneous and impulsive behaviors of juveniles (Ministry of National Research Council, 2018). The fact that they are under protective detention itself results in stress and miscommunications with parents, and in many cases there is no adult or role model who can continue to give advice. As a result, juveniles experience fear of the future, demotivation in life and a gradual decrease in self-esteem that sustains their life (Han and Lee, 2018). Self-esteem is one of the important developmental tasks for general adolescents as well but the emotion is more important to juveniles under protective detention, since self-esteem can determine their emotions, cognition and behaviors (Joung, 2018). Adolescents with high self-esteem show healthy behaviors and adaptability, but those with low self-esteem are less confident and more dependent and show neurotic behaviors such as anxiety and depression. When they try to satisfy their desires and face problems, they also tend to blame others or situations, not themselves for the cause of the problems. In addition, they easily give up or choose an easy path instead of trying to solve problems, which often leads to delinquent behaviors (Woo, 2019). When their desires are not met or they do delinquent behaviors, they are criticized and punished by their parents, teachers and people surrounding them, which lowers their self-esteem further, creating a vicious cycle (Cho and Seo, 2010). The situations and environments, however, can lead to different results depending on their level of recognition of their behaviors (Shin, 2017). How situations and environments are accepted and overcome is determined by the strength of their mind, that is, resilience. Those with high resilience can flexibly think in and respond to any situation, can adopt themselves and use their potential power even in difficult situations, and thus are able to turn the situations into positive ones. Adolescents with low resilience slowly recover from psychological imbalances and tend to maintain potential anger toward unspecified individuals, When they confront any target that triggers their anger, they tend to express all their underlying anger (Wilson et al., 2005). In addition, resilience is not a special ability, but is an ordinary characteristic that makes people think positively, smile, hope for something, give a meaning to their life, be active, ask for help and have relationships with others (Hong, 2006), and it can reduce an impact on negative effects that might experience in stressful situations or crises. Therefore, improving the resilience of juveniles under protective detention is an important element for their healthier rehabilitation to society.

For those who carry out the order of protective detention to improve their possibilities of growth and changes, the Ministry of Justice in charge of handling juveniles under protective detention properly supervises probation officers and provides juveniles with lectures, experience-based learning opportunities, physical and mental training and volunteer activities in cooperation with other government agencies and private resources, and also implements measures to correct their criminal and delinquent behaviors through programs for restoring family functions and providing special education on parenting and laws of everyday life and cultural and art programs. However, the share of violent crimes among juvenile offenders increased from $2.2 \%$ in 2007 to $4.4 \%$ in 2017 , and the share of juvenile offenders who have a criminal record also increased from $29.0 \%$ to $34.6 \%$, indicating that juvenile crimes become more violent and habitual (Ministry of Justice, 2018). Since such experience of crimes in the adolescent period is highly likely to be passed to adulthood, it is important to ensure they are no longer exposed to other crimes by intensively correcting and reforming their delinquent behaviors in the adolescent period considering the social cost of crimes. In addition, given that the original purpose of juvenile protective detention is to correct them not in a detention facility but in society and help them return to society, it is necessary to make new changes in correction and rehabilitation programs operated under the juvenile protective detention policy.

According to Kaplan and Kaplan (1989), a forest as a space for giving a feeling of freedom from daily life can reduce stress and fatigue that stressed-out people in modern times experience and restore them, and Shin (2012) reported that experiencing forests different from everyday environments makes people have a sense of awe and curiosity about nature and a mindset of caring and respecting them- 
selves and surroundings. As such, forest therapy programs operated in forests that can relax the body and mind and improve resilience provide activities that can improve the immunity of the body and restore physical and mental health by utilizing various environmental elements that exist in forests. Walking along forest trails using trails, a forest element, is one of the exercises conducted in forests that have been reported to reduce stress, activate parasympathetic nerves (Lee et al., 2014), reduce negative emotional states and the concentration of cortisol (Lee et al., 2011), increase immunity (Li et al., 2009), and improve the physiological functions of the body. In addition, meditation activities in forests conducted as a psychotherapy relax the body and reduce depression (Lee and Shin, 2015) and diastolic blood pressure and the activation of NK cells are induced to improve immunity (Yang et al., 2011). Aroma therapies utilizing phytoncide positively affect stress, emotional states and sleeping in daily life by stimulating the sense of smell (Choi et al., 2016). Seeing the landscape of forests reduces negative emotional states such as stress, tension and depression increases vitality (Kim et al., 2013). Activities in forests utilizing the various effects of forests have been researched, and one study conducted in Aspen in the United States (Forest Healing Center) reported that violence prevention and healing programs that mainly focused on the healing and restoration functions of forests reduced delinquent juveniles' anxiety, depression, anger, aggressiveness and stress (Ministry of Forest Science, 2014). Programs using forest activities for multi-cultural adolescents who experience difficulties in school life due to differences in language and culture were reported to increase ego resilience (Kang et al., 2019), and experience in forests also positively changes the recognition of middle school students who experience maladjustment in school on natural environments (Shin, 2013).

These studies reported that activities in forests can give adolescents psychological stability as well as positive changes, but they mostly focused on general adolescents. There have been only few studies on those in special circumstances including juveniles under protective detention. Against this backdrop, this study aimed to examine the effects of a forest therapy program operated in a forest for juveniles under protective detention on their self-esteem which allows them to value and positively accept themselves and resilience which allows them in any circumstance to flexibly embrace its environment and restore positivity.

\section{Research Methods}

\section{Subjects}

This study conducted a forest therapy program called "A Dreamy Child, One More Forest!" for one night and two days 13 times for a total of 122 juveniles under protective detention in Seoul and Gyeonggi-do. Most of the participants were males (96.7\%) and the number of those aged 17 years was highest (35 persons, 28.7\%). In terms of their academic background, the number of those enrolled in middle and high school was 69 (56.0\%) and that of those who dropped out or did not enter higher-level schools was $39(31.9 \%)$. The detailed results were as shown in Table 1.

\section{Program execution}

\section{Program content}

Subjects participated in the forest therapy program operated in the Saneum Healing Forest for one night and two days. The healing forest created in Yangpyeong, Gyeonggi-do is designated as the first national healing forest in Korea and the total size of the forest is about 2000 ha. Coniferous, decideous and mixed forests accounted for $24.76 \%, 68.21 \%$

Table 1. General characteristics

\begin{tabular}{|c|c|c|c|}
\hline \multicolumn{2}{|c|}{ Classification } & $\mathrm{n}$ & $\%$ \\
\hline \multirow{2}{*}{ Gender } & Male & 118 & 96.7 \\
\hline & Female & 4 & 3.3 \\
\hline \multirow{3}{*}{ Year of birth } & $1998-2000$ & 40 & 32.8 \\
\hline & 2001 & 35 & 28.7 \\
\hline & 2002-2005 & 47 & 38.5 \\
\hline \multirow{5}{*}{$\begin{array}{l}\text { Academic } \\
\text { background }\end{array}$} & Middle school enrolled & 25 & 15.6 \\
\hline & Middle school drop out & 6 & 4.9 \\
\hline & High school enrolled & 50 & 41.0 \\
\hline & High school drop out & 33 & 27.0 \\
\hline & High school graduate & 14 & 11.5 \\
\hline
\end{tabular}


and $7.03 \%$ respectively. Coniferous trees include Pinus densiflora, Pinus koraiensis, Larix kaempferi and Pinus rigida and decideous trees include Quercus acutissima, Betula platyphylla, Castanea crenata and Zelkova serrata. Its underlying layer of vegetation is composed of Stephanandra incisa, Lindera obtusiloba, Ligustrum obtusifolium, Lespedeza bicolor and Rhus trichocarpa. The altitude is between $200 \mathrm{~m}$ and $1,000 \mathrm{~m}$, and trails of different slopes (3-9\%) are available for different programs and the average yearly wind speed is very low $(1.2 \mathrm{~m} / \mathrm{s})$. According to Jeong (2017), the level of phytoncide in the Saneum Healing Forest in 2016 and 2017 was found to be highest in summer, followed by fall, spring and winter, and the concentration started to increase in April and reached the highest point in September. As the water in the valley along the trails is abundant and thus produce a large amount of anions and its accessibility is also good, it is suitable for operating climatotherapies.

The content of the forest therapy program was composed in consideration of the forest therapy elements and environment of the Saneum Healing Forest and the characteristics of subjects and was led by two forest therapists. The program was largely divided into three sections, and the first was entering the forest (forest exercise and self-introduction) with the goals of raising participants' interest in forests through the five senses, establishing closeness between participants and being prepared for accepting a new environment. The second section was staying in the forest (five-sense awakening walking, the dream of trees and my dream, slow walking meditation, lying down and looking up the sky, night walking). The activities aimed to relax the body and mind, meet the world with different eyes and learn different life styles in forests through healing activities using natural materials and walking meditation and to turn their view open toward the outside only into their inside, looking back on themselves in the past and thinking about my future. The last section was finding their dream in the forest on the next day (dream over dream, phytoncide breathing meditation, hammock healing, forest scent therapy), which aimed to give them an opportunity for finding their dream and vision through healing in the forest. In addition, they were encouraged to understand that the life of the forest, the life of themselves and tress are all connected to each other and to establish their future dream and vision by acquiring the positivity of the forest and my positivity. The detailed content of the program is as shown in Table 2.

\section{Process of executing the forest therapy program}

The forest therapy program in this study was led by two forest therapists and two probation officers attended the program together to encourage any participants who were left behind not to give up, joined with participants during games to improve their immersion in the program, and participated in the entire program for their safety. The length and content of each activity were adjusted considering the level of immersion and conditions of participants. Participants gathered at the entrance of the healing forest at 11 a.m. on the first day and were informed of and answered a questionnaire survey. They were also informed of cautions and the entire schedule of the program. After placing their baggage in their room and having lunch, they had a time for relax and gathered again at the entrance of the forest. Cautions about activities in the forest were mentioned again and they walked into the forest. The detailed content of the forest therapy program is as shown in Table 2. After finishing the program at 11 a.m. on the next day, they answered another questionnaire survey and shared their feelings after participating in the program with others. After that, they returned home with the probation officers and the detailed schedule of the program was as shown in Table 3.

\section{Measurement tools}

\section{Self-Esteem Scale (SES)}

As a scale to measure self-esteem, Rogenberg's Self-Esteem Scale (RSES) that was developed by Rogenberg (1965, as cited in Song, 2004), was translated into Korean by Jeon (1974, as cited in Song, 2004) and was revised by Song (2004) was used in this study. The scale is composed of a total of 10 questions: six positive questions on the belief that they are valuable and can work well with their good personality and four negative questions on the feeling that they are mostly a failure and are useless. A 5-point Likert's scale was used. The reliability (Cronbach's $\alpha$ ) of the scale measured by Song (2004) was .84 and in this study 
Table 2. Contents of the forest therapy program

\begin{tabular}{|c|c|c|c|c|}
\hline $\begin{array}{l}\text { Time } \\
(\min )\end{array}$ & $\begin{array}{l}\text { Program } \\
\text { contents }\end{array}$ & Purpose & $\begin{array}{l}\text { Forest healing } \\
\text { factor }\end{array}$ & Place \\
\hline 20 & Forest gymnastics & $\begin{array}{l}\text {-Enhancing physical vitality } \\
\text {-Widening the range of motion of } \\
\text { the joint } \\
\text {-Injury prevention }\end{array}$ & Terrain movement & \multirow{2}{*}{$\begin{array}{l}\text {-A spacious and flat space, about 50M from } \\
\text { the forest entrance } \\
\text {-The sound of water can be heard, shrubs such } \\
\text { as lace-shrubs and rhododendrons dominate, } \\
\text { and right amount of sunlight makes visitors } \\
\text { feel comfortable }\end{array}$} \\
\hline 30 & Self-introduction & $\begin{array}{l}\text {-Ice-breaking time } \\
\text {-Enhancing intimacy }\end{array}$ & Social factors & \\
\hline 20 & $\begin{array}{l}\text { Sense awakening } \\
\text { walking }\end{array}$ & $\begin{array}{l}\text { Enhancing vitality through } \\
\text { sensory activation }\end{array}$ & $\begin{array}{l}\text { Five senses, terrain } \\
\text { movement }\end{array}$ & $\begin{array}{l}\text {-Altitude } 280-290 \mathrm{~m} \\
\text {-Slope of } 2-5 \% \text { inclination, mixed forest, and } \\
\text { has a valley beside, which makes it possible } \\
\text { to walk listening to the sound of water } \\
\text {-Can stimulate auditory sensation and gain } \\
\text { psychological comfort } \\
\text {-Able to be healed by forest scenery by } \\
\text { walking on the open road }\end{array}$ \\
\hline 30 & $\begin{array}{l}\text { Dream of a tree } \\
\text { and my dream }\end{array}$ & $\begin{array}{l}\text { Thinking of my dream through } \\
\text { the dream of tree }\end{array}$ & $\begin{array}{l}\text { Biological elements, } \\
\text { psychological factor, social } \\
\text { factors }\end{array}$ & $\begin{array}{l}\text {-Space about } 8 \mathrm{~m} \text { wide at the end of walking } \\
\text {-There are several types of broad-leaved trees }\end{array}$ \\
\hline 20 & $\begin{array}{l}\text { Slow walking } \\
\text { meditation }\end{array}$ & $\begin{array}{l}\text { Deep relaxation with active } \\
\text { parasympathetic nervous system }\end{array}$ & $\begin{array}{l}\text { Psychological factor, } \\
\text { biological elements, } \\
\text { social factors }\end{array}$ & $\begin{array}{l}\text {-Forest road with a width of } 1.5 \mathrm{~m} \text { and a slope } \\
\text { of } 5 \% \text { to } 7 \% \\
\text {-There are many shrubs, so there are many } \\
\text { birds which sing }\end{array}$ \\
\hline 30 & $\begin{array}{l}\text { Lying down and } \\
\text { looking up the sky }\end{array}$ & $\begin{array}{l}\text {-Relaxation of the mind that comes } \\
\text { with relaxation of the body } \\
\text {-Looking from a different } \\
\text { perspective }\end{array}$ & $\begin{array}{l}\text { Climatic material elements, } \\
\text { psychological factor }\end{array}$ & $\begin{array}{l}\text {-Sun-covered forest with mixed trees and } \\
\text { shrubs } \\
\text {-Meditation area with individual decks }\end{array}$ \\
\hline 90 & Night walking & $\begin{array}{l}\text { Using darkness to organize inner } \\
\text { feelings }\end{array}$ & $\begin{array}{l}\text { Five senses, psychological } \\
\text { factor }\end{array}$ & $\begin{array}{l}\text {-Forest trail which has width of } 4 \mathrm{~m} \text {, and slope } \\
\text { of } 3 \%-5 \% \\
\text {-Has no lighting equipment }\end{array}$ \\
\hline 40 & $\begin{array}{l}\text { Dream over dream } \\
\text { storytelling }\end{array}$ & $\begin{array}{l}\text { Sharing and expressing the } \\
\text { concrete ways to realize dreams }\end{array}$ & $\begin{array}{l}\text { Psychological factor, social } \\
\text { factors }\end{array}$ & $\begin{array}{l}\text {-Forest road } 2.5 \mathrm{~m} \text { wide with herbaceous, } \\
\text { shrubs and trees }\end{array}$ \\
\hline 20 & $\begin{array}{l}\text { Phytoncide } \\
\text { breathing } \\
\text { meditation }\end{array}$ & $\begin{array}{l}\text { Promote psychological stability } \\
\text { through breathing }\end{array}$ & $\begin{array}{l}\text { Climatic material elements, } \\
\text { psychological factor }\end{array}$ & $\begin{array}{l}\text {-Meditation area composed of pine trees and } \\
\text { individual meditation decks }\end{array}$ \\
\hline 30 & Hammock healing & $\begin{array}{l}\text {-Stress relief } \\
\text {-Appreciating the scenery }\end{array}$ & $\begin{array}{l}\text { Biological elements, } \\
\text { climatic material elements, } \\
\text { psychological factor }\end{array}$ & -Pine tree forest aged around 50 \\
\hline 30 & $\begin{array}{l}\text { Scent of forest } \\
\text { therapy }\end{array}$ & $\begin{array}{l}\text {-With phytoncide oil } \\
\text {-Improving nerve stability and } \\
\text { intimacy }\end{array}$ & $\begin{array}{l}\text { Five senses, climatic } \\
\text { material elements, social } \\
\text { factors }\end{array}$ & $\begin{array}{l}\text {-Flat space next to the forest road in the form } \\
\text { of a basin which is mainly consist of pine } \\
\text { trees }\end{array}$ \\
\hline
\end{tabular}

Cronbach's $\alpha$ was .85 . The detailed results were as shown in Table 4.

\section{Resilience Scale for Adolescents (RSA)}

The resilience of juveniles under protective detention was measured using the Resilience Scale for Adolescents
(RSA) that was developed for adolescents and validated by Joo and Lee (2011). The scale is composed of three sub-factors, including trust in self and others, problem solving ability and patience with negative emotions, and has a total of 23 questions. A self-reporting 5-point scale was used, and the higher the characteristics of each factor, the 
Table 3. Detailed schedule for two days of forest therapy program

\begin{tabular}{|c|c|}
\hline Time & Contents \\
\hline \multicolumn{2}{|r|}{ Day 1} \\
\hline 11:00-12:00 & $\begin{array}{l}\text { - Arrive } \\
\text { - Orientation and fill in the consent form } \\
\text { - Physiological and psychological test(pre) }\end{array}$ \\
\hline $12: 00-13: 30$ & - Check in, lunch, break time \\
\hline 13:30-17:00 & - Program 'Go to the forest' \\
\hline 17:00-20:00 & $\begin{array}{l}\text { - Break time } \\
\text { - Having dinner made by myself }\end{array}$ \\
\hline $20: 00-21: 30$ & - Program 'Stay in the forest' \\
\hline $21: 30-$ & - To the dream land \\
\hline \multicolumn{2}{|r|}{ Day 2} \\
\hline 07:00 & $\begin{array}{l}\text { - Get up } \\
\text { - Morning walk }\end{array}$ \\
\hline 08:00-09:00 & - Breakfast \\
\hline 09:00-11:00 & - Program 'Finding a dream in the forest' \\
\hline 11:00-12:00 & $\begin{array}{l}\text { - Finish } \\
\text { - Physiological and psychological test(post) } \\
\text { - Sharing feelings }\end{array}$ \\
\hline
\end{tabular}

Table 4. Reliability of item composition and measurement tools by sub-factors of self- esteem

\begin{tabular}{ccc}
\hline Constituent factor & Item count & Cronbach' $\alpha$ \\
\hline Positive self-esteem & 6 & .86 \\
Negative self-esteem & 4 & .80 \\
Total & 10 & .85 \\
\hline
\end{tabular}

Note. Negative self-esteem questions were reverse scored.

Table 5. Reliability of item composition and measurement tools by sub-factors of resilience

\begin{tabular}{ccc}
\hline Constituent factor & Item count & Cronbach' $\alpha$ \\
\hline Trust in self and others & 11 & .91 \\
Problem solving ability & 6 & .86 \\
Patience with negative emotions & 6 & .84 \\
Total & 23 & .95 \\
\hline
\end{tabular}

higher the score of its sub-factor. Cronbach's $\alpha$ was originally .87 and in this study was .95 . The detailed results were as shown in Table 5.

\section{Data analysis}

To examine the effects of activities of the forest therapy program on the self-esteem and resilience of juveniles under protective detention, differences in their scores before and after participating in the program were analyzed using a statistical program (SPSS ver. 21.0). To survey the general characteristics of participants and the reliability of the questionnaire surveys conducted in this study, frequency and reliability analyses were conducted, and a paired t-test was used to compare and analyze the mean value of the two variables extracted from the same population. The statistical significance was $p<.05$.

\section{Results and Discussion}

\section{Effects of the forest therapy program on the self-esteem of juveniles under protective detention}

The effects of the forest therapy program conducted in this program on the self-esteem of juveniles who carried out the order of protective detention was verified as shown in Table 6.

As shown in Table 6, the average value of self-esteem increased from 3.102 before the program to 3.636 after the program, showing a significant difference $(p<.001)$. 'Positive self-esteem,' one of the sub-factors of self-esteem increased from 3.107 before the program to 3.880 after the program $(p<.001)$. The mean value of 'negative self-esteem' also increased from 3.096 before the program to 3.270 after the program, but the difference was not statistically significant $(p=.134)$. These results indicate that the forest therapy program positively improved the self-esteem of juveniles under protective detention, and were identical to the results of earlier studies that forest therapy programs improved the self-esteem of children and adolescents from low-income and disadvantaged families (Choi and Koh, 2014; Kim et al., 2015; Kim, 2011; Lee, 2017; Lee et al., 2017; Ryu and Kim, 2012). Self-esteem as a psychological factor that rises from the deep inside seems to give a sense of escape for people to feel that they escape from physical and mental stress in urban life where their image is easily 
Table 6. Comparisons of self-esteem before and after the forest therapy program

\begin{tabular}{|c|c|c|c|c|c|}
\hline \multicolumn{2}{|c|}{ Classification } & M & SD & $t$ & $p$ \\
\hline \multirow{2}{*}{$\begin{array}{c}\text { Total } \\
\text { self-esteem }\end{array}$} & Pre & 3.102 & 0.634 & \multirow{2}{*}{6.963} & \multirow{2}{*}{$<.001^{* * * *}$} \\
\hline & Post & 3.636 & 0.662 & & \\
\hline \multirow{2}{*}{$\begin{array}{c}\text { Positive } \\
\text { self-esteem }\end{array}$} & Pre & 3.107 & 0.710 & \multirow{2}{*}{9.371} & \multirow{2}{*}{$<.001^{* * *}$} \\
\hline & Post & 3.880 & 0.693 & & \\
\hline \multirow{2}{*}{$\begin{array}{c}\text { Negative } \\
\text { self-esteem }\end{array}$} & Pre & 3.096 & 0.817 & \multirow{2}{*}{1.509} & \multirow{2}{*}{.134} \\
\hline & Post & 3.270 & 1.059 & & \\
\hline
\end{tabular}

exposed (Choi et al., 2015). Beautiful visual stimuli, olfactory stimuli like phytoncide, auditory stimuli like the sound of birds and water, elements that stimulate the five senses like anions, and meditation programs that give opportunities of slowly and deeply experiencing forests seem to give participants who suffer from the result of actions performed in a distorted state experience of looking deep inside of themselves. Positive stimuli such as actively choosing program activities and relaxing the body and mind also seem to improve their self-esteem. These results are in line with the results of the following studies. Jeong et al. (2012) reported that forest elements and activities affected emotional stability, and Yeoun (2007) reported that a forest therapy program comprised of activities such as meditation in forests and experience of laboring in nature improved the self-esteem of those with drinking problems. Lee et al. (2003) reported that a forest bath program improved the self-esteem of college students with depression and anxiety. Shin (2003) pointed out that exposure to forest environments provides people with an environment where they can return to their human nature and have eco-friendly sensitivity and positive perception of their own life and that the experience can be transferred to daily life. As such, the transferred experience created by positive activities in forests seemed to improve self-esteem. This indicates that positive activities and experience in forests improve the self-esteem of those who have a weak connection with social support and experience psychological and social difficulties due to changes in emotions in the process of growth such as juveniles under protective detention.
Table 7. Comparisons of resilience before and after the forest therapy program

\begin{tabular}{|c|c|c|c|c|c|}
\hline Classification & & M & SD & $t$ & $p$ \\
\hline \multirow{2}{*}{ Total resilience } & Pre & 2.950 & .675 & \multirow{2}{*}{10.820} & \multirow{2}{*}{$<.001^{* * *}$} \\
\hline & Post & 3.829 & .650 & & \\
\hline \multirow{2}{*}{$\begin{array}{l}\text { Trust in self } \\
\text { and others }\end{array}$} & Pre & 3.014 & .756 & \multirow{2}{*}{9.509} & \multirow{2}{*}{$<.001^{* * *}$} \\
\hline & Post & 3.870 & .684 & & \\
\hline \multirow{2}{*}{$\begin{array}{c}\text { Problem } \\
\text { solving ability }\end{array}$} & Pre & 2.929 & .666 & \multirow{2}{*}{11.280} & \multirow{2}{*}{$<.001^{* * *}$} \\
\hline & Post & 3.818 & .670 & & \\
\hline \multirow{2}{*}{$\begin{array}{c}\text { Patience with } \\
\text { negative emotions }\end{array}$} & Pre & 2.854 & .725 & \multirow{2}{*}{10.167} & \multirow{2}{*}{$<.001^{* * *}$} \\
\hline & Post & 3.765 & .727 & & \\
\hline
\end{tabular}

Note. $\mathrm{N}=122$.

${ }^{* * *} p<.001$ by paired t-test.

\section{Effects of the forest therapy program on the resilience of juveniles under protective detention}

The effects of the forest therapy program conducted in this program on the resilience of juveniles who carried out the order of protective detention was verified as shown in Table 7.

As shown in differences in the level of resilience before and after participating in the program (Table 7), the mean value increased from 2.950 before the program to 3.829 after the program, showing a significant difference $(p<.001)$. By sub-factor, the mean value of trust in self and others increased from 3.014 to 3.870 ; that of problem solving ability, from 2.929 to 3.818 ; and that of patience with negative emotions from 2.854 to 3.756 . The mean value of all the sub-factors increased after participating in the forest therapy program, showing statistically significant differences $(p<.001)$. The results coincided with the results of the following studies. M.H. Kim (2014) reported that children from disadvantaged families showed after participating in eight straight sessions of a forest therapy program active attitudes towards building relationships by displaying positive ego-functions in terms of trust in self and others. Lee and Jegal (2018) reported that the group of college students with maladjustment problems who joined art activities after experiencing forests showed significant changes in all sub-factors including interpersonal relationships, self-regulation and positivity compared to the group of students who did not receive any treatment. 
The increasing positive effects of resilience seemed to naturally increase the frequency of meetings with others while participants performed activities and experienced forests in groups. Inner closeness seemed to be improved by achieving the shared goal of providing a healing program in a natural harmony with lives in forests, which also seemed to improve the function of trust in self and others, one of the sub-factors of resilience. These results coincided with the results of earlier studies that reported statistically significant changes caused by improved interpersonal relationships after experiencing forests (Oh et al., 2012; Park et al., 2012). In addition, forests give a sense of escape and openness in daily life (Shin et al., 2007). Such opportunities allow participants to feel no burden of learning and producing results and a sense of escape from the restraint of negative emotions and to discover the experience of solving problems in the process of performing and achieving tasks to a certain level in the program and positive attitudes toward themselves discovered after having the experience of success (Jang et al., 2019). Night walking conducted at a dark night aimed to give participants time to reflect on themselves and discover visions. Direct encountering the darkness of nature allows people to turn their eyes that always head towards the outside into the inside and look inside of themselves, which seemed to result in significant changes in patience with negative emotions, a base for individuals' inner abilities. These results coincided with the results of the following studies. Lee et al. (2011) reported that the negative emotions of male college students were reduced after walking in forests for three days, and Han (2019) reported that walking and meditation in forests restored the loss in the attention of elderly people and thus improved their emotions and feelings as well as their resilience. As the findings above show, positive activities in forests seem to increase the resilience of participants, the strength of their mind that can transform current situations into positive ones.

\section{Conclusion}

This study was conducted with the aim of examining the effects of forest therapy activities provided for 122 ju- veniles who carried out the order of protective detention on their self-esteem that allow them to value and positively accept themselves and on their resilience which allows them to embrace and overcome any situation and environment. Based on the results obtained in this study, the following conclusions were reached.

First, the self-esteem of juveniles under protective detention increased after participating in the activities of the forest therapy program operated in this study. Positive self-esteem as its sub-factor increased and showed statistically significant results. Negative self-esteem also showed an increase, but the results were not statistically significant. Therefore, the forest therapy program seems to affect the positive attitudes of juveniles under protective detention towards their value.

Second, resilience is a useful concept for identifying the core ability and attitudes of adolescents that help them positively grow, and its sub-factors including trust in self and others, problem solving ability and patience with negative emotions showed an increase in their mean value after participating in the program with statistically significant differences. Therefore, it can be concluded that the forest therapy program positively affected the resilience of juveniles under protective detention.

These results indicated that the forest therapy program provided for juveniles under protective detention increased their self-esteem and provided opportunities for building their positive inner power. In addition, the program was found to increase their resilience with which they can positively perceive their value and what is happening and actively respond to the stress and problematic situations caused by it. There were limitations in this study. As this study was conducted on a single group without any control group, it is difficult to generalize the results, and thus it will be necessary to set and compare a control group in a follow-up study. This study operated a short-term program of one night and two days, but in the follow-up study it will be necessary to compare differences in the effects of the program depending on its length and to examine how long its positive effects will last. 


\section{References}

Cho, E.S. and J.M. Seo. 2010. Factors influencing children's mental health state. J. Korean Acad. Psychiatr. Ment. Health Nurs. 19(1):57-66.

Choi, J.H., H.J. Kim, C.S. Shin, P.S. Yeon, and J.S. Lee. 2016. The effect of 12-week forest walking on functional fitness, self-efficacy, and stress in the middleaged women. J. Korean Inst. For. Recreat. 20(3):27-38. https://doi.org/10.34272/forest.2016.20.3.003

Choi, S.J. and Y.S. Koh. 2014. Effect of combined program of horticultural therapy and forest therapy on self-esteem, social competence, and life respect of low-income family children at community children's center. J. Sch. Soc. Work. 29:671-698.

Choi, S.W., J.Y. Mok, M.S. Kim, A.S. Chung, J.W. Han, J.M. Woo, K.W. Kim, and B.J. Park. 2015. The impact of forest therapy on neuro-cognitive, psychosocial, and physiological aspects of adolescent internet addiction risk group. J. Korean For. Soc. 104(2):277-284. https://doi.or $\mathrm{g} / 10.14578 / \mathrm{jkfs} .2015 .104 .2 .277$

Han, I.D. 2019. The effect of forest healing program on the resilience of elderly people in urban forest. Master's thesis, Chungbuk National University, Cheongju, Korea.

Han, J.Y. and S.E. Lee. 2018. Effects of multimedia group art therapy program for adolescent under probation. CONTENTS PLUS [J. Korean Soc. Media Arts] 16(2): 35-36.

Hong, E.S. 2006. Conceptual understanding of resilience and instructional suggestion. Korean J. Spec. Educ. 41(2):45-67.

Jang, C.S., C.S. Shin, B.S. Jang, and O. Sharif. 2019. Effects of forest healing programs using school forests on language acquisition and ego-resilience of multicultural background students. Korean J. Environ. Ecol. 33(3): 333-340. https://doi.org/10.13047/KJEE.2019.33.3.333

Jeong, M.A., S.J. Park, J.H. Lee, C.W. Park, and J.J. Kim. 2012. A case study on the effects of forest environmental factor on human psychological and physiological responses. J. Korean Inst. For. Recreat. 16(3):13-19. https://doi.org/10.34272/forest.2012.16.3.002

Jeong, S.Y. 2017. Phytoncide emission trend analysis: A focus on Saneum Recreation Forest. Master's thesis, Kookmin University, Seoul, Korea.
Joo, S.Y. and Y.H. Lee. 2011. Development and validation of the resilience scale for adolescents(RSA). Korea J. Youth Stud. 18(4):103-139.

Joung, D.W. 2018. Developing and evaluating the Korea Green Gym as citizen participatory forest management activities based on the forest welfare. Master's thesis, Chungnam National University, Daejeon, Korea.

Kang, Y.M., W.S. Shin, and S.J. Lee. 2019. The effect of group art therapy using forest experience art activities on ego resilience of multicultural adolescents. Multicult. Educ. Stud. 12(2):111-130. https://doi.org/10.14328/ME S.2019.6.30.111

Kaplan, R. and S. Kaplan. 1989. The experience of nature: A psychological perspective. New York, NY: Cambridge University Press.

Kim, E.Y. 2014. Effects of clinical art therapy on anger, aggression and ego resilience of school adolescent with maladjustment. Master's thesis, CHA University, Pocheon, Korea.

Kim, J.H., W.T. Kim, and Y.H Yoon. 2013. Beneficial effect of green landscape on relieving stress of citizen in urban area. Korean J. Environ. Ecol. 27(4):516-523.

Kim, M.H. 2014. A study on the positive effects of forest activities for children from economically underprivileged households on their emotional state, life satisfaction, and ego-resilience. Korean J. Child Stud. 35(4):223-247. https://doi.org/10.5723/KJCS.2014.35.4.223

Kim, S.A., D.W. Joung, G.W. Kim, and B.J. Park. 2015. The effect of forest activities on attitude toward forest and mental health of elementary school students. J. Korean Inst. For. Recreat. 19(4):35-43. https://doi.org/1 0.34272/forest.2015.19.4.004

Kim, Y.S. 2011. The influence of forest therapeutic program on the depression and self-esteem of middle school students in WEE class. Master's thesis, Chungbuk National University, Cheongju, Korea.

Lee, H.E., W.S. Shin, P.S. Yeoun, Y.M. Cho, and S.H. Yeom. 2011. Effects of inhalation of essential oil (Chamaecyparis obtusa) on stress and depression in college students. J. Korean Inst. For. Recreat. 15(2):61-68. https://doi.org/10.34272/forest.2011.15.2.007

Lee, J. 2017. A study on the stress relief effects of adolescent physical activity in city parks. Doctoral dissertation, Seoul National University, Seoul, Korea. 
Lee, J., B.J. Park, Y. Tsunetsugu, T. Ohira., T. kagawa, and Y. Miyazaki. 2014. Effect of forest bathing on psychological and physiological responses in young Japanese male subjects. Public Health 125(2):93-100. https://doi.org/10.1016/j.puhe.2010.09.005

Lee, J.H., J.Y. Hong, and Y.R. Tae. 2017. Analysis of change of emotion and self-esteem of at-risk children through forest activities. J. Korean Inst. For. Recreat. 21(3):1-9. https://doi.org/10.34272/forest.2017.21.3.001

Lee, S.I., W.S. Shin, Y.M. Kwon, and H.K. Kwon. 2003. The effect of woods aromatic substance. J. Korean Inst. For. Recreat. 7(4):25-29.

Lee, S.J. and S.A. Jegal. 2018. Effects of forest art experience group art therapy program on ego resilience of university students and adaptation to college life. J. Clin. Art Psychother. 8(3):47-70. https://doi.org/10.34167/cliart. 8.3.201812.47

Lee, Y.J. and C.S. Shin. 2015. Effects of forest walking meditation on mood states and self-awareness in middleaged women. J. Korean Inst. For. Recreat. 19(3):19-25. https://doi.org/10.34272/forest.2015.19.3.003

Li, Q., M. Kobayashi, Y. Wakayama, H. Inagaki, M. Katsumata. Y. Hirata, K. Hirata, T. Shimizu, T. Kawada, B.J. Park, T. Ohira, T. Kagawa, and Y. Miyazaki. 2009. Effect of phytoncide from trees on human natural killer cell function. Int. J. Immunopathol. Pharmacol. 22(4):951-959. https://doi.org/10.1177/039463200902200410

Ministry of Forest Science. 2014. Forest service program in North America. Seoul, Korea: Author.

Ministry of Justice. 2018. Crime analysis-2018. Seoul, Korea: Author.

Ministry of National Research Council. 2018. A study on the comprehensive countermeasures for youth fight prevention and crisis youth support. Sejong, Korea: Author.

Oh, C.H., S.G. Park, T.S. Park, and I.J. Oh. 2012. The development and effects of the forest experience program for the internet addiction teenagers. Korean J. Couns. 13(5):2395-2415. https://doi.org/10.15703/kjc. 13.5.201210.2395

Park, H.W., H.Y. Kim, M.R. Huh, B.G. Son, K.B. Lim, W.C. Park, and I.S. So. 2012. Effect of horticultural therapy on activities of daily living and interpersonal relation of institutionalized intellectual disabilities. J. Agric. Life Sci. 46(3):11-17.

Rye, S.Y. and M.H. Kim. 2012. Psychological healing effect through ecological experience -A case study of Green-Camp participants in 2012. Int. J. Tour. Manag. Sci. 27(5):157-176.

Shin, G.H. 2017. A study on resilience type of the juvenile delinquents. Forum Youth Cult. 51:99-127. https://doi.or g/10.17854/ffyc.2017.07.51.99

Shin, K.H. 2013. A study on development of school violence prevention program that applied forest therapy and effectiveness: Centering on middle school students with inability to adapt to school. Doctoral dissertation, Chungbuk National University, Cheongju, Korea.

Shin, W.S. 2003. Forest sociology. Seoul, Korea: Ttanim Publishing.

Shin, W.S. 2012, January 26. Using forest healing function to prevent school violence. Dong-A Ilbo. Retrieved from http://www.donga.com/news/article/all/20120126/43555 $750 / 1$

Shin, W.S., P.S. Yeoun, J.H. Lee, S.K. Kim, and J.S. Joo. 2007. The relationships among forest experience, anxiety and depression. J. Korean Inst. For. Recreat. 11(1):27-32.

Song, N.O. 2004. University student's stress, self-control, self-esteem and internet usage. Master's thesis, Yeon Sei University, Korea.

Wilson, G.S., M.E. Pritchard, and B. Revalee. 2005. Individual differences in adolescent health symptoms: The effects of gender and coping. J. Adolesc. 28(3): 369-379. https://doi.org/10.1016/j.adolescence.2004.08. 004

Woo, J.H. 2019. A study on the reduction of offenses of juvenile probation subjects through coaching. Master's thesis, Baekseok University, Seoul, Korea.

Yang, E.S., S.H. Seo, K.S. Jeong, H.R. Yoon, D.H. Lee, and B.G. Hwang. 2011. Effects of short-term meditation and walking exercise in a forest on blood pressure, heart rate, NK-cell and POMS. Kinesiology 13(3):31-40.

Yeoun, P.S. 2007. The relationships between forest experience and depression. J. Korean Inst. For. Recreat. 11(3):1-6. 